\title{
Metáfora, alegoría y nostalgia: La casa en las novelas de Alejandro Zambra
}

\author{
Metaphor, allegory and nostalgia: \\ The house in the novels written by Alejandro Zambra
}

\begin{tabular}{c} 
BIEKE WILLEM \\
\hline $\begin{array}{c}\text { Universiteit Gent. Gent, Bélgica } \\
\text { bieke.willem@ugent.be }\end{array}$
\end{tabular}

\section{RESUMEN}

El título de la tercera novela de Alejandro Zambra, Formas de volver a casa, señala que la casa ocupa el centro espacial de la narración. Este artículo examina primero la imagen de la casa evocada en las tres novelas de Zambra como una metáfora de la literatura y después como el punto centrípeto en una serie de representaciones de la experiencia postdictatorial. La primera parte de esta contribución se basa en las teorías de Heidegger y de Deleuze y Guattari sobre el habitar. A continuación mostraremos que la nostalgia reflexiva descrita por Boym nos permite leer los movimientos narrativos que giran alrededor de la casa en las novelas de Zambra como alegorías de la experiencia postdictatorial. Con tal motivo se propone asimismo situar la producción de Zambra frente a los conceptos de alegoría forjados por Avelar y por De Man.

Palabras clave: Habitar, nostalgia reflexiva, postdictadura, metáfora y alegoría.

\section{ABSTRACT}

The title of the third novel by Alejandro Zambra, Formas de volver a casa, presents the house as the centre of the narration. This article examines first the house, as it is described in Zambra's novels, as a metaphor for literature, and then as the centripetal point of a series of representations of postdictatorial experience. The first part of the article is based on the theories of Heidegger and Deleuze and Guattari about living. In the second part, the concept of reflexive nostalgia, developed by Boym, permits 
us to consider the narrative movements around Zambra's house as "allegories" of postdictatorial experience. Therefore, the article aims at determining the position of Zambra's literary production in light of the concepts of allegory forged by Avelar and De Man.

Keywords: Dwelling, reflexive nostalgia, post-dictatorship, metaphor and allegory.

Recibido: 13.03.2012. Aceptado: 10.09.2012.

\section{FORMAS DE HABITAR: LA CASA COMO METÁFORA DE LA LITERATURA}

T a palabra hogar se traduce en alemán, neerlandés e inglés como respectivamente Heim, thuis y home. Contrariamente a lo que ocurre en estas lenguas germánicas, la palabra española no conserva los rastros de una raíz común con la palabra casa (haus, huis, house), con la que coincide en el sentido de un lugar que ofrece amparo. La palabra casa refiere generalmente a una construcción física, un edificio. En combinación con determinadas preposiciones y pronombres posesivos puede adquirir el mismo significado que la palabra hogar (véanse las expresiones esta es tu casa, sentirse como en su casa), o sea, el de refugio, de privacidad, de pertenencia.

En La poétique de l'espace de Bachelard (1957) convergen las dos nociones que se suelen asociar con la casa: como edificio y como hogar. Para el fenomenólogo francés, la casa se basa en dos principios: de la verticalidad y de la centralidad. La casa de Bachelard es definida por una polaridad entre el sótano y la buhardilla. Además, es un punto estable, una fuente de seguridad ontológica en un mundo que parece cada vez más extraño, cada vez más fragmentado: "La maison, dans la vie de l'homme, évince des contingences, elle multiplie ses conseils de continuité. Sans elle, l'homme serait un être dispersé. Elle maintient l'homme à travers les orages du ciel et les orages de la vie. Elle est corps et âme. Elle est le premier monde de l'être humain" (Bachelard, 1957: 26).

Algunos años antes de la publicación de La poétique de l'espace, Heidegger había cuestionado la evidencia con la que se solía igualar las nociones de casa y hogar. En un ensayo titulado "Construir, habitar, pensar" se preguntó si "[las viviendas] albergan ya en sí la garantía de que acontezca un habitar?" (Heidegger, 1991: 45). Aunque sin duda simplificamos de esta manera irremediablemente la teoría de Heidegger, podemos asociar el habitar acerca del cual escribe con la noción de hogar. 
A base del ensayo de Heidegger, y a base de un capítulo titulado "Del ritornelo", publicado en Mil mesetas: capitalismo y esquizofrenia de Deleuze y Guattari (2004), podemos deducir que la casa, como hogar, se constituye de dos elementos claves: primero, tenemos la casa sinónimo de dominio y protección, la casa que podemos representar por una frontera entre un centro interior, que debe ser protegido, y el caos del mundo exterior. El segundo elemento lo constituyen las posibilidades de apertura de esta frontera, las líneas de fuga descritas por Deleuze y Guattari. De esta manera, la casa también es un lugar desde donde se inicia el descubrimiento del mundo.

En La vida privada de los árboles, la segunda novela de Alejandro Zambra publicada en 2007, volvemos a encontrar estos dos elementos en los títulos de las dos partes que construyen la novela: "Invernadero" e "Invierno". En "Invernadero", todo ocurre en el amplio departamento de Julián, Verónica y Daniela en La Reina, una comuna acomodada de Santiago. A partir de este espacio cerrado, Julián nos presenta escenas retrospectivas de su vida con su expareja Karla y explica cómo ha llegado a vivir en el departamento de La Reina. Se empeña en inventar historias sobre árboles para hacer dormir a Daniela, la hija de su mujer Verónica. Una vez que la niña está dormida, inventa un futuro para ella, mientras recuerda imágenes de su infancia y nos cuenta sobre la novela que está escribiendo. La ficción funciona de esta manera como una capa de protección contra la vida real: mientras escribe Julián, no ve los problemas de su expareja Karla; mientras inventa las historias sobre la vida privada de los árboles, se puede imaginar que Verónica llegará a casa.

Como lo insinúa Zambra en un reportaje de Canal 13 en el que le pidieron trazar su propio Santiago, la imagen del invernadero proviene de un poema de Enrique Lihn (1963), titulado precisamente "Invernadero". En este poema, publicado en La pieza oscura, Lihn utiliza la imagen del invernadero para hablar sobre la memoria y la existencia de vida artificial, de ficción, en otras palabras: "Las hojas nada dicen que no esté claro en las hojas. Nada dice la / memoria / que no sea recuerdo" (30). En el reportaje, Zambra lleva al entrevistador al antiguo invernadero de Quinta Normal, uno de los parques más grandes de la capital. Como en el poema de Lihn, el invernadero está completamente destruido, "lleno de vidrios rotos" (29). Sólo puede servir a los mendigos que duermen allí en invierno, en las palabras de Zambra, como una "intemperie más cómoda". El invernadero, la

\footnotetext{
${ }^{1}$ Reportaje audiovisual “Trazo mi ciudad”, primera temporada. Disponible en http://www. trazomiciudad.cl/.
} 
ficción, es entonces únicamente una capa de protección extremadamente frágil contra el mundo real.

En la segunda parte, titulada "Invierno", Julián y Daniela abandonan el departamento donde viven para afrontar la lluvia e ir a la escuela. Es el día siguiente, el día en que Julián se ha dado cuenta de que Verónica no llegará a casa. Esto significa el final de la novela, porque "el libro sigue hasta que ella vuelva o hasta que Julián esté seguro de que ya no va a volver" (Zambra, 2007: 17, 38). Aquí empieza la confrontación con el mundo, con la vida fuera de la ficción. En La vida privada de los árboles encontramos entonces una analogía muy clara entre la casa y la ficción: la casa es al mundo exterior lo que el libro es a la realidad. Ambas, casa y ficción, ofrecen una protección, aunque precaria, contra la vida exterior. De esta manera, la imagen de la casa sirve de metáfora de la literatura. El habitar como metáfora del escribir.

Las historias y las imágenes que configuran la segunda novela de Zambra parten de un espacio en el que, aunque sólo procura una protección precaria, el protagonista se siente en casa. Las historias inventadas en el departamento en La Reina proporcionan al protagonista, al mismo tiempo, la frontera (aunque frágil) que protege contra el mundo exterior y las líneas de fuga. En cambio, en Bonsái, la primera novela de Zambra, todos los espacios interiores parecen demasiado estrechos, incómodos y poco acogedores como para hablar de una verdadera casa en el sentido heideggeriano y bachelardiano. La pieza de servicio donde comienza el romance entre Emilia y Julio, el escenario de "casas prestadas", y "moteles de sábanas que olían a pisco sour" (Zambra, 2006: 29), la habitación sobrepoblada de Emilia en Madrid y el piso subterráneo de Julio muestran las mismas señas "de incomodidad, de familiaridad culpable, de vergüenza, de vacío” (Zambra, 2006: 58) que caracterizan la conversación entre Emilia y Anita en Madrid. En estos espacios escasamente descritos es difícil encontrar el primer sentido que atribuimos a la casa, es decir, la ilusión de que desde dentro se puede dominar el mundo exterior. Si seguimos con la metáfora que La vida privada de los árboles nos ha permitido establecer, la imposibilidad de habitar debería encontrar aquí su equivalente metaficcional. Resulta en efecto insostenible el deseo de los personajes de vivir como personajes y al mismo tiempo vivir una vida real. Tras la lectura de "Tantalia”, el cuento de Macedonio Fernández (1977) que pone de manifiesto el paralelismo entre la manipulación de una plantita y la de los personajes de una novela, Julio y Emilia se dan cuenta de que la pieza en la que hacen el amor ya no puede convertirse en el carruaje blindado de Madame Bovary.

En Bonsái, como en todas las novelas de Zambra, esta vida real, este 
mundo fuera de la literatura es brumoso. Pensamos solamente en el estatuto ambiguo de Emilia y Julio entre personaje y persona ${ }^{2}$. Siempre existe el peligro de que, como en el poema de Lihn, "allí afuera no hay nadie" (1963: 30), de que fuera del invernadero que es la ficción, existe un vacío. O un semivacío, porque como lo señala una reseña de las traducciones al neerlandés de Bonsái y La vida privada de los árboles, Zambra siempre "trata de sugerir de manera muy sutil un mundo más allá del texto" (De Ridder, 2011: s.p., mi traducción).

El semivacío que encontramos fuera de la literatura en las novelas de Zambra parece plasmarse en el espacio concreto $^{3}$ de la novela: el mundo fuera de los espacios cerrados en la novela consta únicamente de algunos topónimos, unos pocos complementos adverbiales de lugar y verbos de movimiento. El narrador nos habla de una esquina en Providencia, de un barrio en Madrid, sin describir realmente el espacio ${ }^{4}$. Zambra casi no hace uso de lo que Pimentel llama "la forma privilegiada para generar la ilusión del espacio" (Pimentel, 2001: 8) y para significar el espacio en la narrativa: la descripción. No utiliza muchos adjetivos calificativos u otros elementos que podríamos llamar operadores tonales ${ }^{5}$, y que permiten la transición del nivel denotativo al nivel connotativo del espacio. Lo que predomina, en cambio, en la manera en que Zambra construye el espacio en Bonsái, son los verbos que describen los movimientos de los personajes. En muchos casos se trata de verbos que refieren a una separación o un alejamiento. Pensamos no solamente en las partidas de Emilia y María a Madrid que construyen de alguna manera el relato, sino también en las partidas del primer plano de la novela, como en el siguiente fragmento:

[María] Camina hacia la librería Fuentetaja, porque aquella tarde ha que-

2 "Emilia y Julio -que no son exactamente personajes, aunque tal vez conviene pensarlos como personajes" (Zambra, 2006: 33).

${ }^{3}$ Utilizamos aquí la noción de espacio concreto, en el sentido en el que Katrin Dennerlein lo definió en su libro Narratologie des Raumes (2009), es decir, en un sentido estrictamente nometafórico. El espacio concreto de la novela es el espacio perceptible por los personajes de la novela.

${ }^{4}$ En "Wrapped trees: una lectura de Bonsái, de Alejandro Zambra", Felipe Toro parece señalar el mismo semivacío espacial cuando observa que los protagonistas de esta novela, Julio y Emilia, "caminan por el espacio abierto, a la manera de cuerpos flotantes" (s.p.).

5 "El adjetivo, el adverbio, y toda clase de frases cuya función sea calificativa" cumplen, en las palabras de Pimentel, con "una importante función tonal; textualmente, actúan como operadores tonales, cuya redundancia semántica -porque habrá de notarse que no es exactamente el mismo lexema el que se repite, sino el mismo campo semántico al que se afilian todos los diversos lexemasgenera una isotopía tonal disfórica y desvalorizante" (Pimentel, 2001: 27), o al contrario, eufórica y valorizante. 
dado en la librería Fuentetaja con un pretendiente que tiene. No importa el nombre del pretendiente, salvo porque en el trayecto piensa, de pronto, en él, y en la librería y en las putas de la calle Montera y también en otras putas de otras calles que no vienen al caso, y en una película, en el nombre de una película que vio hace cinco o seis años. Es así como empieza a distraerse de la historia de Emilia, de esta historia. María desaparece de camino a la librería Fuentetaja. Se aleja del cadáver de Emilia y comienza a desaparecer para siempre de esta historia (Zambra, 2006: 89).

El espacio concreto representado en la novela se confunde con el espacio de la ficción, lo que refuerza el juego metaficcional que caracteriza las tres novelas de Zambra ${ }^{6}$.

Pero por neblinoso que sea el espacio fuera de las casas, los pisos y las piezas descritas en Bonsái, observamos sin embargo una fuga hacia este afuera. Como lo indica Lucero de Vivanco, se "[instala] el extravío por la ciudad sobre el arribo al hogar" (2010: s.p.). La última escena, en la que Julio decide no volver a su departamento y en lugar de eso viajar en taxi por Santiago, confirma en efecto que las líneas de fuga de las que hablaron Deleuze y Guattari tienen aquí más importancia que la frontera que protege la casa de Heidegger.

El título de la tercera novela de Zambra, Formas de volver a casa, ya indica que se presenta aquí el movimiento opuesto: no es una fuerza centrífuga sino centrípeta la que propulsa el relato. La casa paterna, situada en el barrio de Maipú de los años 80 forma el centro alrededor del cual se construye una novela sobre la dictadura chilena. Tanto en Formas de volver a casa como en La vida privada de los árboles, que anticipa a ésta, el escritor se detiene frecuentemente en la fachada de las casitas de Maipú construidas a finales de los años 70. La blancura -blanco invierno- y las flores del antejardín forman claramente una frontera entre la vida privada y el mundo político de la dictadura. Cómo cada fachada se dirige hacia el mundo exterior, proclamando un mensaje de inocencia, de discreción, de apoliticidad. Cumple completamente con la función protectora de la casa, hace de la casa "una especie de fortaleza en miniatura, un reducto inexpugnable" (Zambra, 2011: 30). Aún más que las escenas familiares que tiene que proteger, esta fachada testimonia del miedo que caracterizaba los años de dictadura. En este sentido sustituye quizás la cara que falta, según el niño, a los padres: "nuestros

\footnotetext{
${ }^{6}$ Para un estudio detallado de la metaficción en Bonsái, véase el artículo de Macarena Silva, "La conciencia de reírse de sí, metaficción y parodia en 'Bonsái' de Alejandro Zambra” (2007).
} 
padres nunca tienen cara realmente. Nunca aprendemos a mirarlos bien" (Zambra, 2011: 18). Con una frontera tan fortificada, las líneas de fuga son, entonces, escasas. Sin embargo, el niño de la primera parte consigue pasar el día vagando por las calles de la ciudad. El protagonista adulto de las otras partes parece haber sustituido este vagabundeo por la escritura, lo que resulta en las novelas que se analizan en el presente artículo.

Junto con los intentos narrativos de volver a casa, el narrador-adulto (el narrador 'real' de la segunda y cuarta parte de la novela) se esfuerza en hacer suyo un espacio, de construir una casa en el sentido de un verdadero hogar después de la partida de su mujer Eme:

Un día de éstos esta casa ya no va a recibirme. Quería habitarla de nuevo, ordenar los libros, cambiar los muebles de lugar, arreglar un poco el jardín. Nada de eso ha sido posible. Pero me ayudan, ahora, varios dedos de mezcal (Zambra, 2011: 53).

Las actividades ordenar, cambiar, arreglar refieren todas a lo que para Heidegger era una condición imprescindible del habitar: franquear un espacio, ordenar las cosas en su lugar.

Este intento de hacer suyo un espacio lo encontramos también en la actitud de la adulta Claudia, la amiga del narrador de la tercera parte. Como observa éste, ella "ocupa el espacio [del departamento del narrador] como reconociéndolo. Cambia frecuentemente de silla, se pone de pie, de pronto se sienta en el suelo y se queda un rato con las manos en los tobillos" (Zambra, 2011: 111). Podemos interpretar su conducta como una forma de tratar de sentirse en casa, no sólo en el departamento del narrador, sino también en Chile, el país que dejó atrás hace varios años. La lucha con su hermana por el poder de decisión sobre la casa paterna cabe igualmente en este deseo de aferrarse a una casa propia en Chile.

Pero el intento del narrador de hacer suya la casa de su mujer fracasa y Claudia finalmente parte de nuevo a Estados Unidos. Las formas de habitar, al igual que las formas de volver, no son más que experimentos. Como lo observa acertadamente Gonzalo Garcés, Formas de volver a casa explora sobre todo "los efectos de la pérdida de las estructuras que sirven como abrigo" (2011: s.p.).

Según el paralelismo entre la casa y la ficción que establecimos por medio de La vida privada de los árboles, el deseo de volver a casa expresado en la última novela de Zambra debería corresponder a un deseo de volver a la ficción. Sin embargo, es al revés, como lo ha confirmado el autor en varias 
entrevistas, en Formas de volver a casa hay una preferencia de la vida real por sobre la ficción ${ }^{7}$. El narrador de esta novela nos advierte repetidamente de los peligros de la ficción. Cuando su hermana le pregunta por qué ella no saldrá en su libro, el narrador 'real' responde: "para protegerte" (Zambra, 2011: 82). De nuevo se confirma aquí que la ficción sólo puede proveer una ilusión de protección. Es un invernadero cuyas ventanas se rompen demasiado fácilmente. Por eso, "es mejor no salir en ningún libro / Que las frases no quieran abrigarnos" (Zambra, 2011: 153). Vuelta a la vida real, entonces, pero mediante los intentos narrativos que cuentan sobre diferentes vueltas a casa, es decir: volver a la vida mediante la ficción.

\section{FORMAS DE VOLVER: ALEGORÍAS NOSTÁLGICAS DE LA EXPERIENCIA POSTDICTATORIAL}

Hasta ahora hemos seguido rigurosamente una estructura bipolar: la del interior y del afuera de la casa que nos permite ver en ella una metáfora de la literatura. Tanto la casa como la literatura pueden ofrecer una forma de protección contra el caos del mundo exterior. Pero en Allegories of reading, Paul De Man critica precisamente esta visión estrictamente binaria, de que la literatura sería una caja que separa el interior del exterior (1979: 5). Zambra, por su parte, al mismo tiempo que invita a sus lectores a considerar la literatura como una casa, o como un invernadero, comparte la reticencia de De Man ante una idea que se considera quizás demasiado fácilmente como verdad: que haya una clara separación entre el mundo de la ficción y el mundo de la realidad, y que sólo el crítico literario tenga acceso al contenido de la ficción, que sólo él sepa decodificar su forma.

Como hemos visto, la metáfora casa-literatura se manifiesta de manera más clara en la segunda novela de Zambra. En la primera y la tercera, sin embargo, es mucho más difícil mantenerla: la literatura se revela como una capa de protección muy frágil contra el mundo exterior, y, además, ya no es tan claro dónde termina el mundo interior y dónde empieza la vida fuera de la literatura. Se puede decir que en Bonsái y en Formas de volver a casa, la metáfora se apoya precisamente en la borrosidad de la frontera entre in-

${ }^{7}$ Zambra dice en una entrevista con La Tercera que "de pronto [sintió] la necesidad de la honestidad absoluta" (Careaga C. s.p.). De Bonsái a Formas de volver a casa asistimos en efecto a un acercamiento al material narrado por parte del escritor, lo que refuerza el aspecto autoficcional. La ficción y la vida se integran progresivamente. Parece que en Formas de volver a casa llegamos finalmente a la equivalencia perfecta entre la novela y el bonsái: "un bonsái no es un árbol bonsái porque la palabra ya contiene al elemento vivo" (Zambra, 2006: 86). El elemento vivo en la tercera novela de Zambra lo constituyen los recuerdos de infancia de los años 1984-1985. 
terior y exterior tanto espacial como literario. Pero acabamos de ver que en la última novela el paralelismo "vuelta a casa - vuelta a la ficción" se vuelve paradójico: volver a casa significa aquí volver a la vida real, pero mediante la ficción. Sin querer seguir el radical deconstructivismo de De Man, entonces proponemos en lo que sigue ir más allá de la metáfora de la casa-literatura para ver si es posible insertarla en una alegoría.

La alegoría es una figura retórica que nace, según Idelber Avelar (2000), desde una imposibilidad de la representación. El crítico brasileño relaciona esta derrota literaria con una derrota política, la de los ideales revolucionarios de los años 70 en América Latina. La alegoría sería entonces una característica esencial de la literatura postdictatorial, la única figura que puede relatar lo ocurrido. Pero los orígenes de su definición de la alegoría se encuentran en un contexto muy alejado de las sociedades latinoamericanas. Se basa en los estudios de Walter Benjamin sobre el drama barroco. El Trauespiel alemán es traducido por Avelar como un "lutiludio" (2000: 18), un drama en que los elementos de juego y duelo son igualmente importantes.

Podríamos calificar las novelas de Zambra también de "lutilúdicas". El aspecto lúdico se observa más claramente en los juegos metaficcionales (la parodia, la mise en abîme, la intertextualidad) y en la ironía. Ambas técnicas, frecuentemente asociadas con una escritura postmoderna, provocan un distanciamiento con respecto a lo narrado. En Formas de volver a casa, el uso de la voz del niño parece aspirar al mismo efecto. Es en esta tercera novela en la que entra en escena más claramente el otro lado del lutiludio: el duelo.

No obstante, el duelo sigue manifestándose de una manera indirecta. En Formas de volver a casa, el narrador insiste en algo que ya ha sido mencionado en la novela anterior: no hay muertos en su familia. Y sin la presencia de muertos, una novela sobre la dictadura resultaría quizás un poco pobre en comparación con novelas (testimoniales) y películas anteriores que tematizan la dictadura. Por eso necesita contar la historia de su amistad con Claudia, cuyo padre era un fugitivo del régimen de Pinochet. De esta manera, su novela se convierte realmente en una novela de la generación de los niños que crecieron durante la dictadura, porque abarca tanto las vidas de los que sintieron directamente sus consecuencias como las vidas de las personas para quienes la dictadura era una historia ajena.

El terremoto de 2010 con que concluye la novela permite en cierto sentido reunir estos dos grupos. El narrador, miembro del último grupo, piensa "ingenuamente, intensamente en el dolor [...] en los muertos de ayer, de mañana. Y en este oficio extraño, humilde y altivo, necesario e insuficiente: pasarse la vida mirando, escribiendo" (Zambra, 2011: 164). Zambra señala 
aquí de algún modo que la tarea del escritor consiste precisamente en darse cuenta de ese dolor ajeno, y registrarlo. Así se acerca a la tarea "mnemónicarestitutiva" que Avelar (2000: 30) adscribe al artista postdictatorial. Sin embargo, Bonsái, La vida privada de los árboles y Formas de volver a casa están muy lejos de las novelas estudiadas por Avelar. Diamela Eltit, Joao Gilberto Noll, Tununa Mercado y Ricardo Piglia alegorizan una realidad que es mucho más traumática que la de Zambra. La "madre de las alegorías y su contenido" (Benjamin, 1985: 230, mi traducción), el duelo, que se asocia en el contexto de la dictadura chilena con muertos, tortura y desapariciones, está sólo presente en la última novela, indirectamente, como trasfondo borroso. O sea que el relato de Zambra regresa a esta temática, pero a partir de estrategias muy diferentes de las consagradas por la ficción de hace veinte años. Para el niño que Zambra era en 1988, el mayor centro de detención de Santiago, el Estadio Nacional, no fue nada más que una cancha de fútbol (Zambra, 2011: 119).

Como se ha observado en varias reseñas de las novelas de Zambra, ese duelo camuflado se manifiesta bajo la forma de la melancolía, es decir, de un duelo incumplido según las teorías de Freud. En la tercera novela se convierte más claramente en nostalgia, esa "tristeza melancólica originada por el

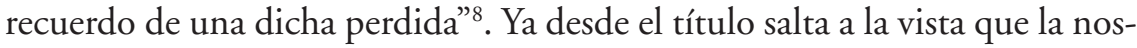
talgia es el motor de la narración, visto que, etimológicamente, la palabra se compone de nostos (volver a casa) y algia (anhelo). Sin embargo, el deseo de recuperar las imágenes de su infancia no es, según el escritor-protagonista de Formas de volver a casa, un acto nostálgico. Afirma rotundamente: "estoy contra la nostalgia” (Zambra, 2011: 62). Pero de inmediato matiza:

No, no es cierto. Me gustaría estar contra la nostalgia. Dondequiera que mire hay alguien renovando votos con el pasado. Recordamos canciones que en realidad nunca nos gustaron, volvemos a ver a las primeras novias, a compañeros de curso que no nos simpatizaban, saludamos con los brazos abiertos a gente que repudiábamos.

Me asombra la facilidad con que olvidamos lo que sentíamos, lo que queríamos. La rapidez con que asumimos que ahora deseamos o sentimos algo distinto (Zambra, 2011: 62)

El protagonista refiere aquí a una observación esencial en el trabajo de Svetlana Boym sobre la nostalgia, a saber, que este nostos, que anhelamos

\footnotetext{
${ }^{8}$ Diccionario de la Real Academia Española.
} 
tanto, en realidad nunca ha existido. Nostalgia, según Boym, "is a longing for a home that no longer exists or has never existed. Nostalgia is a sentiment of loss and displacement, but it is also a romance with one's own fantasy" (2001: XIII). La nostalgia contiene entonces una dimensión utópica, lo que puede explicar la popularidad del fenómeno en nuestros tiempos de globalización, catástrofes naturales y tecnología avanzada.

En busca del futuro perdido. Cultura y memoria en tiempos de globalización de Andreas Huyssen es una reflexión sobre la emergencia de la memoria como preocupación principal de las sociedades occidentales. Esta vuelta al pasado se explica por el "deseo de anclarnos en un mundo caracterizado por una creciente inestabilidad del tiempo y por la fracturación del espacio en el que vivimos" (Huyssen, 2002: 24). Cuando el narrador de Formas de volver a casa ve en todas partes "alguien renovando votos con el pasado", está observando entonces un fenómeno global. Pero no podemos perder de vista que la vuelta al pasado en Chile adquiere un particular peso político, nacional, que explica por qué el narrador quiere resistir a la nostalgia. Muchas veces, la nostalgia todavía es un tabú porque, en palabras de Boym, sería "an abdication of personal responsibility, a guilt-free homecoming, an ethical and aesthetic failure" (2001: XIV). Volver a los años ochenta de Chile movido por la nostalgia sería entonces no sólo preferir el kitsch por sobre el noble trabajo de la memoria, sino también esquivar la responsabilidad, embellecer ese pasado reciente en que se torturaba y se hacía desaparecer a gente. En una entrevista con la revista Qué pasa sin embargo, Alejandro Zambra dice que su intención ha sido revisar esa nostalgia ochentera que actualmente está de moda también en Chile". Afirma el autor: "Me gustaría reconstruir ese mundo con una mirada que no cayera en los alardes de culpa y de inocencia” (Díaz Oliva, 2011: s.p.).

Esta revisión de la nostalgia se lleva a cabo de varias maneras. Primero, para evitar que su novela sobre la dictadura sólo se redujera a una historia sobre la culpa y la inocencia, ha sido necesario añadir, a los capítulos que cuentan los 80 desde la mirada de un niño, otras partes, escritas a partir del presente, que ofrecen contextualización y el intento de comprender a los padres acomodaticios. Segundo, la opción por Maipú, este "mundo de mentira" (Zambra, 2011: 65), en vez del centro de Santiago que representa más claramente la nación en estado de sitio, la cruda realidad de la dictadura, significa una ruptura con la literatura más tradicional, nostálgica, so-

\footnotetext{
${ }^{9}$ Una prueba de eso es la popularidad de la teleserie Los 80, de Canal 13.
} 
bre la capital chilena ${ }^{10}$. Como acabamos de ver, el paisaje de Maipú refleja mejor que el centro la apoliticidad de sus habitantes. Además, las diferencias urbanísticas entre la villa en la que crece el niño y el mismo barrio al que vuelve el escritor adulto años más tarde, muestran mejor la evolución social y económica de la sociedad chilena después de la dictadura ${ }^{11}$.

Finalmente, el lenguaje sobrio, característico de la escritura de Zambra, también puede ser visto como una manera de evitar el kitsch con que se asocia generalmente la nostalgia. Pero el intento de Zambra para revisar la nostalgia tiene implicaciones más profundas en la manera de narrar. El tipo de nostalgia que Zambra parece profesar se acerca mucho a lo que Svetlana Boym denomina nostalgia reflexiva que, a base de la doble etimología de la palabra, se opone a la nostalgia restaurativa: "Restorative nostalgia stresses nostos and attempts a transhistorical reconstruction of the lost home. Reflective nostalgia thrives in algia, the longing itself, and delays the homecoming - wistfully, ironically, desperately" (2001: XVIII).

Las novelas de Zambra ilustran a la perfección esta particular postura nostálgica: están plagadas de múltiples escenas que posponen la vuelta a casa. Así, como hemos visto a lo largo de este texto, las tres novelas de Zambra pueden ser resumidas en tres movimientos que giran alrededor de ese eje que es la casa. En Bonsái, detectamos un movimiento de alejamiento de los espacios interiores, una preferencia por el vagabundeo por la ciudad sobre el arribo a casa. La vida privada de los árboles está construida sobre la espera de Julián a que vuelva a casa su mujer. Es decir, a que vuelva a completar la casa, porque "Verónica es alguien que ligeramente falta en la pieza azul" (Zambra, 2007: 15). Sin ella, es imposible que el departamento en La Reina cumpla con todas las características que lo hacen "casa" en el sentido de "hogar". Lo mismo ocurre en Formas de volver a casa. Como hemos visto, al narrador "real" de la segunda y cuarta parte le es imposible hacer suya la casa porque falta la presencia de su mujer Eme. Proyecta entonces sus esfuerzos hacia ese otro centro, la casa de sus padres.

Si tomamos como definición básica de la alegoría que es un relato que hace posible representar lo irrepresentable ${ }^{12}$, podemos considerar estos tres

\footnotetext{
${ }^{10}$ Para un comentario de esta literatura del Santiago 'revisitado' véase el ensayo de Jaime Lizama (2007).

${ }^{11}$ Pensamos en la privatización del espacio, el anonimato de la gran ciudad, la iniciativa individual de los habitantes de la villa que modificaron considerablemente sus casas, alguna vez todas uniformes.

${ }^{12}$ Algunos teóricos consideran la alegoría como una metáfora continuada (Lausberg 1975: 212), lo que es refutado por otros que la prefieren calificar como un conjunto de símbolos (Marchese y Forradellas, 1989: 20). Podemos considerar este 'conjunto' como una construcción narrativa en
} 
movimientos, o construcciones literarias que giran alrededor de la casa, como alegorías nostálgicas.

Podemos relacionar el foco de las tres alegorías en la casa, este nostos al que se intenta infructuosamente volver, con ciertas preferencias estéticas que Boym asocia con la nostalgia reflexiva. Según ella, "Reflective nostalgia does not follow a single plot but explores ways of inhabiting many places at once and imagining different time zones; it loves details, not symbols" (2001: XVIII). La tercera novela de Zambra responde totalmente a esta descripción. Los capítulos 'ficticios' que repiten la vuelta a casa 'real' del narrador exploran en efecto diferentes maneras de narrar esta vuelta a casa, que se extiende por diferentes niveles de ficción. También hacen saltar a la vista la atención por el detalle, el registro minucioso de la vida cotidiana.

Tomamos a modo de ejemplo los dos fragmentos que narran la conversación entre el narrador adulto y su madre a las dos de la mañana. Las páginas 78-80 de la parte intitulada "La literatura de los padres" son repetidas en las páginas 133-135 de la parte "La literatura de los hijos", con algunas ligeras diferencias. La primera conversación, un posible fragmento del diario del escritor (Zambra), registra supuestamente la realidad. La segunda es la transcripción ficticia de la primera y transcurre enteramente en el living de la casa de sus padres en Maipú. La primera conversación en cambio, la 'real', tiene lugar en "una especie de pieza pequeña que construyeron para instalar una inmensa lavadora nueva" (Zambra, 2011: 78). Junto con la atención por los detalles espaciales en este primer fragmento, se registra con minuciosidad los movimientos de la madre: "fumó con el gesto de siempre, tan acentuadamente femenino: el cigarro hacia abajo, la mano mostrando la palma, muy cerca de la boca” (78). La banalidad del escenario continúa en la conversación: la madre y su hijo conversan sobre las novelas de Carla Guelfenbein - una autora best seller chilena- el sentido del humor del narrador y el hecho de que se fue tan temprano de la casa. Esta atención por los detalles cotidianos, banales, está ausente en la segunda conversación 'ficticia', que en el mismo contexto (fumar un cigarrillo con tu madre a las dos de la mañana) aborda los grandes temas, o mejor dicho, el gran tema de la postdictadura chilena: el de la culpa y de la inocencia. En cierto sentido, el narrador de

la que los diferentes elementos (que adquieren un valor simbólico) interactúan de tal manera que se cree otro sentido coherente, generalmente más abstracto, debajo del sentido literal. Es en otras palabras un relato que hace posible representar lo que a primera vista parece irrepresentable. Esta definición ha sido confirmada por, entre otros, Northrop Frye, quien consideró la alegoría como un modo de escribir sobre lo incognoscible o lo inenarrable (Copeland y Struck, 2010: 268). Avelar, por su parte, postuló que "alegórico es todo aquello que representa la imposibilidad de representar" (2000: 247, subrayado en el texto). 
esta tercera parte, "La literatura de los hijos", acusa a su madre de complicidad con el régimen de Pinochet, visto que "al no participar apoyaban a la dictadura" (Zambra, 2011: 132). La madre alega que "[su] padre ha sido siempre un hombre que ama a su familia" (135). De esta manera, parece que el conflicto chileno se puede reducir a un asunto familiar, y es precisamente a lo que Zambra apunta: si la dictadura ha sido una historia de los padres, la postdictadura narra cómo los hijos manejan la herencia de sus padres. El consejo de la madre - "deberías ser un poco más tolerante" $(80,134)$ - refiere tanto a la opinión del autor sobre las novelas de Carla Guelfenbein como a esta herencia.

El escritor se da cuenta, sin embargo, de que introducir los grandes temas de la dictadura en una escena cotidiana, familiar, indudablemente crea un efecto forzado, incómodo. "Siento que en mi lenguaje hay ecos, hay vacíos. Me siento como hablando según un manual de comportamiento" (Zambra, 2011: 132), dice el narrador cuando hace observar la responsabilidad de su familia supuestamente apolítica. Se da cuenta de que repite las palabras de otros, que a veces suena, como lo describe Claudia cuando ella está hablando de su pasado, "como esos sociólogos medio charlatanes que a veces salen en la televisión" (115). La pequeña pieza en la que están fumando el escritor y su madre parece reflejar esa molestia que provoca la inserción de un discurso sociológico en la descripción de escenas familiares. Hace pensar también en el "refugio incómodo" sobre el que Zambra habla cuando le preguntan por el significado de la memoria (Cárdenas, 2007: s.p.).

Todos los elementos de las escenas arriba comentadas, el tema de la conversación entre el narrador y su madre, la atención por los detalles, y sobre todo el marco espacial -una protuberancia de la casa original destinada a alojar una enorme lavadora- son testimonio de una profunda banalidad que se extiende por todas las novelas de Zambra. En eso reside precisamente la gran diferencia con las novelas que Avelar ha estudiado en Alegorías de la derrota: carecen totalmente del 'aura' que el crítico brasileño aún intenta buscar en las obras de Eltit, Noll, Mercado y Piglia. Mientras que los fragmentos y ruinas de las que son construidas estas obras postdictatoriales llevan aún consigo "las semillas de una energía mesiánica" (Avelar, 2000: 286) sobre la que escribió Walter Benjamin, en las imágenes evocadas en las novelas de Zambra falta la dimensión dramática (en el sentido de trágica) del lutiludio.

Además, la ausencia de muertos en la que se insiste en la tercera novela, insinúa que no hay nada indecible, que los narradores de Zambra simplemente no tienen nada que decir. O mejor dicho: ya no tienen nada que decir sobre ese dolor que afectó a sus padres. La derrota de la representación que 
es, según Avelar, una condición esencial de la alegoría, se reduce aquí a un problema generacional: la dificultad de manejar el vacío en el que consiste la herencia de los padres. De ahí la melancolía que impregna las historias de Zambra: dan cuenta de una pérdida, de un vacío, sin que se sepa muy bien qué se ha perdido, qué es lo que no se puede representar. Es más, en las partes autobiográficas de las novelas de Zambra se nota incluso una cierta tristeza por la carencia de duelo, una nostalgia, precisamente, por un hogar fracturado que representara quizás mejor los años de la dictadura. La casa paterna de Zambra no es lo 'irrepresentable'; difiere fundamentalmente de, por ejemplo, la casa perdida por Tununa Mercado que ella intenta recuperar a través de los retazos de un texto literario. Tampoco se parece a la casa de María Canales en Nocturno de Chile, donde Roberto Bolaño (2000) hace convivir perversamente el arte y el horror como una metáfora del país en dictadura. La banalidad de la casa 'autobiográfica' de Zambra requiere entonces los capítulos de ficción (la historia de su amiga Claudia) para seguir teniendo algo que decir.

Quizás sea entonces preferible dejar de lado la teoría sobre la alegoría de Avelar. En artículos más recientes, el crítico admitió que el modelo desarrollado para la literatura postdictatorial en Alegorías de la derrota ya no es válido para una parte importante de la producción literaria contemporánea. Se refiere a autores como Sergio Chejfec, Martín Kohan y Gustavo Ferreyra, "que regresan al pasado dictatorial de Argentina en términos bastante diferentes de aquellos consagrados por la narrativa histórica, alegórica o memorialista de los años 80 . En ellos, las metáforas de la recuperación y de la restauración han visiblemente perdido la vigencia, y la polaridad entre el cómplice y la víctima ha dado lugar a sujetos menos localizables y de posición histórica no tan fácilmente asignable" (Avelar, 2000: 346).

A pesar de que esta descripción cubre perfectamente las novelas de Zambra, preferimos sin embargo guardar el concepto de la alegoría, no necesariamente como una derrota de la representación, sino sobre todo, como lo observó De Man, como un fracaso de la lectura (1979: 205). Como hemos visto, era difícil mantener la imagen de la casa como metáfora de la ficción a causa de los valores ambiguos que se podían adscribir a su interior y exterior. Ambas entidades se revelaban como algo a lo que se tenía que volver y al mismo tiempo algo de lo que cabía huir. Insistimos en considerar estos movimientos como alegorías (nostálgicas), porque esto significa tener en cuenta que la interpretación a veces se corta, que la lectura de las novelas de Zambra como unidad es imposible. Como lo observa Magdalena Perkowska en un artículo sobre Las nubes de Saer, la alegoría no sirve simplemente a 
representar lo irrepresentable, sino que tematiza sobre todo esta diferencia (la no coincidencia) entre la representación y el significado, lo que crea precisamente un "entre-lugar" (s.p.). En las novelas de Zambra sobran siempre residuos que parecen esconderse en los intersticios entre realidad y ficción que el autor construye mediante su complicado juego metaficcional y su lenguaje podado ${ }^{13}$.

¿Deberíamos obedecer al título de su libro de ensayos: No leer? "Las hojas nada dicen que no esté claro en las hojas", suena el poema de Lihn. Pero como No leer también es en realidad una apología para la lectura, se puede tratar de leer algo en estos intersticios. Primero, lo que se esconde en el espacio intermedio formado por las dos primeras novelas de Zambra son las "sobras" ${ }^{14}$ o imágenes de infancia que sólo llegan a concretizarse en la última novela. Pero no sólo se deja entrever allí un pasado, sino también un futuro. Como lo afirma Matthijs De Ridder en su reseña de las dos primeras novelas de Zambra, en estos intersticios se puede ver una forma de escribir contra la derrota política de la que habla Avelar. En Formas de volver a casa se confirma en efecto algo que en las dos primeras novelas sólo es posible intuir: una emergente conciencia política, una nueva izquierda intelectual a la que se pide tolerancia con respecto al pasado, pero que refuta también enérgicamente las huellas reaccionarias de este pasado que parecen haberse anclado definitivamente en la sociedad chilena. El deseo de volver a casa de Zambra no es en absoluto una forma de embellecer el pasado. No obstante, conserva ese aspecto utópico, intrínseco de la nostalgia.

\section{REFERENCIAS}

Avelar, Idelber. (2000). Alegorías de la derrota: la ficción postdictatorial y el trabajo del duelo. Santiago: Cuarto Propio.

Bachelard, Gaston. (1957). La poétique de l'espace. Paris: PUF. Benjamin, Walter. (1985) [1928]. The origin of German tragic drama. Trans. John Osborne. London: Verso.

Bolaño, Roberto. (2000). Nocturno de Chile. Barcelona: Anagrama.

${ }^{13}$ En su artículo sobre lo grotesco en Bonsái, Felipe Toro se centra entre otros en los residuos que han dejado las versiones anteriores de Bonsái (el poema "El alambrado" y el cuento breve "Macedonio"), para ejecutar "una lectura del fragmento" (s.p.). Este tipo de lectura nos parece en efecto lo más adecuado para acercarse a las novelas de Zambra.

${ }^{14}$ Así se titula la verdadera novela de Gazmuri, el escritor cuya obra el protagonista de Bonsái supuestamente transcribe. 
Boym, Svetlana. (2001). The future of nostalgia. New York: Basic books.

Cárdenas, María Teresa. (2007). La literatura no salva a nadie. Revista de Libros de El Mercurio, 22 de abril.

Careaga C., Roberto. (2011). “Tenía la necesidad de recuperar el paisaje de la infancia de los 80". Diario La Tercera, 23 de abril.

Copeland, Rita y Struck Peter T. (2010) The Cambridge companion to allegory. New York: Cambridge University Press.

Deleuze, Gilles y Félix Guattari. (2004). Del Ritornelo. En Mil mesetas. Capitalismo y esquizofrenia (pp. 317-358). Valencia: Pre-textos.

De Man, Paul. (1979). Allegories of reading. Figural language in Rousseau, Nietzsche, Rilke, and Proust. New Haven - London: Yale University Press.

Dennerlein, Katrin. (2009). Narratologie des Raumes. Berlin, New York: De Gruyter.

De Ridder, Matthijs. (2011). De ruimte waar zo heerlijk over te zwijgen valt. Disponible en http://www.dereactor.org/home/detail/de_ruimte_ waarover_zo_heerlijk_te_zwijgen_valt/.

De Vivanco Roca Rey, Lucero. (2010). Bonsái: una novela en escorzo. Disponible en: http://filosofiahumanidades.uahurtado.cl/literatura/academicos/ldevivanco/ldevivanco_bonsai.pdf.

Díaz Oliva, Antonio. (2011). "Los 80 según Zambra”. Revista Qué pasa, 14 de abril.

Fernández, Macedonio. (1977). Tantalia. En Adolfo Bioy Casares, Jorge Luis Borges y Silvina Ocampo (eds), Antología de la literatura fantástica (pp. 91-94). Barcelona: Edhasa-Sudamericana. Disponible en: http:// www.textosenlinea.com.ar/borges/Antologia $\% 20 \mathrm{de} \% 201 \mathrm{a} \% 20$ literatura\%20fantastica.pdf.

Garcés, Gonzalo. (2011). "El silencio de los hijos”. N. Revista de cultura, 24 de junio.

Heidegger. (1991) [1954]. Over denken, bouwen, wonen. Vier essays. Amsterdam: SUN.

Huyssen, Andreas. (2002). En busca del futuro perdido. Cultura y memoria en tiempos de globalización. México D.F.: Fondo de Cultura Económica.

Lausberg, Heinrich. (1975). Elementos de retórica literaria: introducción al estudio de la filología clásica, románica, inglesa y alemana. Madrid: Gredos.

Lihn, Enrique. (1963). La pieza oscura. Santiago: Editorial Universitaria.

Lizama, Jaime. (2007). La ciudad fragmentada. Espacio público, errancia y vida cotidiana. Santiago: Universidad Diego Portales.

Marchese, Angeloy y Joaquín Forradellas. (1989). “Alegoría”. Diccionario de retórica, critica y terminología literaria. Barcelona: Ariel. 
Perkowska, Magdalena. (En prensa). Entre el sentido y la ilegibilidad: Las nubes de Juan José Saer como una narración dialéctica. Sevilla: Universidad de Sevilla.

Pimentel, Luz Aurora. (2001). El espacio en la ficción. Ficciones espaciales. La representación del espacio en los textos narrativos. México D. F.: Siglo XXI editores.

Silva, Macarena. (2007). La concienca de reírse de sí: metaficción y parodia en Bonsái de Alejandro Zambra. Taller de letras, 41, 9-20.

Toro, Felipe. (2011). Wrapped trees: una lectura de Bonsái, de Alejandro Zambra. Revista Laboratorio 5. Disponible en http://www.revistalaboratorio.cl/2011/12/wrapped-trees-una-lectura-de-bonsai-de-alejandrozambra/.

Zambra, Alejandro. (2006). Bonsái. Barcelona: Anagrama. . (2007). La vida privada de los árboles. Barcelona: Anagrama. . (2010). No leer. Crónicas y ensayos sobre literatura. Santiago: Universidad Diego Portales. . (2011). Formas de volver a casa. Barcelona: Anagrama. 